\title{
Does participation in higher education make a difference in life outcomes for students with intellectual disability?
}

\author{
Laura N. Butler*, Kathy Sheppard-Jones, Barry Whaley, Beth Harrison and Michelle Osness \\ Human Development Institute at University of Kentucky, Lexington, KY, USA
}

Revised/Accepted November 2015

\begin{abstract}
.
BACKGROUND: There has been a great migration of students with intellectual disability (ID) into the college world. The Higher Education Opportunities Act of 2008 (HEOA) has opened the door to postsecondary education to a previously untapped market of students. As a result, programs for students with intellectual disability have been developed around the country to support this historic systems change (Lee, 2009). Along with improved job prospects as one important measure of success, college participation also brings opportunity for personal and social development.

OBJECTIVE: With seven years passing since the HEOA, it is prudent to assess outcomes for those students who are choosing to continue their education beyond high school. The National Core Indicators provide a unique opportunity to assess impact of higher education across life domains, historically used to determine developmental disability service system quality of life outcomes. Here, we discuss higher education and outcomes around employment, health, relationships and medications.

METHODS: Students who had completed at least two semesters of college in Kentucky were surveyed about life outcomes using the National Core Indicators (NCI) Adult Consumer Survey (ACS).

RESULTS: Findings on health, medications, employment, and relationships are reported.

CONCLUSION: Participation in higher education can positively impact life outcomes across a variety of domains. This research represents a first step in utilizing a nationally recognized instrument that takes a holistic view of outcomes for adults with IDD to assess impact of participation in higher education. While the results are promising, further studies using larger samples are needed.
\end{abstract}

Keywords: Intellectual disability, higher education, national core indicators

\section{Introduction}

The nature of work in our society is undergoing an evolution. There is an expectation that, by 2018 , $63 \%$ of jobs will require postsecondary education (Carnevale, Smith, \& Strohl, 2011). This means that

*Address for correspondence: Laura N. Butler, 1525 Bull Lea Road, Suite 160, Lexington, KY 40511, USA. Tel.: +1 502320 6030; E-mail: laura.smith2@uky.edu. higher education is not a luxury for students following high school. It is becoming a necessity. In fact, the need for a qualified employment force with postsecondary education cannot be met within the current structure, as the existing postsecondary system won't be able to provide enough graduates to meet the needs of employers (Carnevale, Smith, \& Stohl, 2011). Compounding this issue is the fact that disparities in employment for people with disabilities are well known. Approximately $17 \%$ of 
people with disabilities are employed, versus $64.6 \%$ of those without disabilities (Bureau of Labor Statistics, 2015). For those with intellectual disabilities (ID), the gap widens (Siperstein, Parker, \& Drascher, 2013). The majority of states utilize National Core Indicators data to assess service impact for their constituents with intellectual and developmental disabilities who receive state funded developmental disability supports. NCI data shows that, in Kentucky, only $11 \%$ of adults with ID are employed. NCI provides a holistic view of quality of life across a variety of domains, providing a unique measure of service quality. Domains include relationships, employment, decision making, respect and rights, health and wellness, and access to services (National Core Indicators, 2015).

Recent passage of the Workforce Innovations Opportunities Act (WIOA) shows a recognition that more emphasis must be placed on the critical period around transition. As such, WIOA will focus vocational rehabilitation resources and priorities on those transitioning out of high school (United States Department of Labor). Education pays in a variety of ways, and more education results in higher rates of employment, regardless of disability (Smith, Grigal, \& Sulewsi, 2012; Migliore, Butterworth, \& Hart, 2009). Unfortunately, the expectation for students with ID to attend college has not been well shared or understood by professionals or families (SheppardJones, Kleinert, Druckmiller, \& Kovacavich-Ray, 2015; Thacker \& Sheppard-Jones, 2011), resulting in a transition process that is fragmented and inconsistent across systems (Hong, Ivy, Gonzalez, \& Ehrensberger, 2007). Having employment can add value to a person's life. Employment can also provide people with disabilities the opportunity for "demonstrating skills and competencies and for formulating friendships" (Wagner et al., 2005, p. 5-1).

Attending college can provided benefits for everyone including those with a disability (Grigal, Hart, \& Weir, 2012). Higher education includes any education after high school including vocational school, two-year colleges, or 4-year colleges. Having some kind of higher education can help an individual secure a job (Grigal et al., 2012). Including people with disabilities in higher education is not new, as they have been serving people with intellectual disabilities for over 30 years. Further, The Higher Education Opportunity Act of 2008 provides opportunities to universities to increase their programs for people with intellectual disabilities (Ross, Marcell, Williams, \& Carlson, 2013).
The National Longitudinal Transition Study - 2 (NLTS-2) showed that there was an increase in higher education participation among most disability categories (Wagner, Newman, Cameto, \& Levine, 2005). Higher education participation still remains low and almost unchanged from 1987 survey to the 2003 survey for people with intellectual disabilities (Wagner et al., 2015).

Universities and college are doing many activities to support and encourage employment after leaving their institution; $81 \%$ of surveyed institutions are providing employment support to their students with intellectual disabilities (Grigal et al., 2012). This support comes in forms of job shadowing, internships, and job development and placement services (Grigal et al., 2012). These supports could potentially help individuals find employment after completing studies. Taft College created the Transition to Independent Living to assist and educate individuals with intellectual disabilities (Ross et al., 2013). Of the graduates from this program Ross et al. (2013) found that $84 \%$ had paid employment. This continues to suggest that higher education is important for increasing employment outcomes.

Smith, Grigal, \& Sulewski (2012) found that individuals with or without a disability who attained a higher education had a higher rate of employment. It was found that $43 \%$ of individuals with a cognitive disability and some college credit were employed, compared to only $31 \%$ with a regular high school diploma were employed. Attaining some amount of higher education can potentially impact the career paths of people with disabilities; it is important to include them in higher education opportunities. Further Migliore, Butterworth, \& Hart (2009) that individuals with intellectual disabilities were more likely to be employed with higher paying jobs if they received some higher education. Migliore et al. (2009) found that vocational rehabilitation agencies can support the inclusion of individuals in higher education which resulted in these individuals leaving vocational rehabilitation with paid employment.

Kentucky has had focused efforts in higher education since 2008. In this study, we examine the life outcomes for individuals who have experienced higher education. Specifically, we will look at: community participation, relationships, choice making, employment, respect and rights, and health and wellness. Results for students in higher education will be compared with the state's overall NCI results. This will enable us to determine if differences exist between the groups and ask: Are there differences in 
life outcomes for adults with ID who attend a college or university versus those who do not?

\section{Methodology}

We surveyed life outcomes for students who have completed at least two semesters of college in Kentucky using the National Core Indicators (NCI) Adult Consumer Survey (ACS) (National Core Indicators, n.d.). We analyzed results in comparison to the state's ACS results. We used the results of the NCI Adult Consumer Survey (ACS) and the Background Section of the Survey.

Nineteen students represented the student group (response rate $=51.4 \%$ ). The non-student group consisted of 158 people between the ages of 18-30 in Kentucky who had been randomly selected to participate in NCI from the universe of people receiving state developmental disability waivers, ICF, and state general funding in the most recent data cycle (2013-2014). We used the Statistical Package for Social Sciences (SPSS) version 22.0 to generate descriptive and inferential statistics in order to measure differences between the two groups on a variety of life outcomes. This manuscript focuses on areas recognized by the state's Quality Improvement Committee as lagging behind the country and the general population: namely health, medications, employment, and relationships.

\section{Results}

\subsection{Health}

Over $73 \%$ of the student group had gone out for exercise in the past month, versus $37 \%$ of the NCI young adult group. The student group also reported higher levels of overall health, with over $83 \%$ of students indicating "good" or "excellent" health, as opposed to $62 \%$ of the NCI young adult group.

\subsection{Medications}

Of the student group, $50 \%$ were taking at least one psychotropic medication. This was less than the 69\% of the young adult group.

\subsection{Employment}

Thirty-seven percent of students were employed in the community while $13 \%$ of the NCI young adult sample were employed. A full $100 \%$ of students who were not working wanted to work, versus $53.4 \%$ of the young adult group. Two-thirds (66.7\%) of students also volunteered, while $24.3 \%$ of NCI did volunteer work.

\subsection{Relationships}

Approximately $83 \%$ of the student group had friends to talk to or do things with, while $54.2 \%$ of the non-student group reported having friends. The NCI group were at a slight advantage in terms of loneliness, with $45.8 \%$ indicating they were sometimes or often lonely. A full $50 \%$ of the student group self-reported loneliness. However, all of the student group (100\%) had opportunities to help others, versus $44.2 \%$ of the young adult group.

\section{Discussion}

It appears that participation in higher education can positively impact life outcomes across a variety of domains. It also further indicates that the loneliness indicator is multi-faceted, and lends support to the notion that, while students are included in integrated and inclusive higher education settings, true inclusion may not be taking place. To date, this is the first study of its kind, using a tool that has been adopted by a majority of states as a marker of service quality for individuals with developmental disabilities. The data from the NCI survey has continued to encourage state agencies to push "Employment First" polices rather than day service (Bershadsky, Butterworth, \& Hierteiner, 2014). Results of this small study support the relationship of higher education and community based competitive employment. Beyond the employment implications, participants in this study were at an advantage in terms of psychotropic medications, health and exercise, ability to help others, and opportunities to volunteer. It could be surmised that the higher education environment is supportive of all of these areas. The fact that the students were as lonely as non-students makes us continue to consider the opportunities that students have to develop genuine friendships Additional research is warranted, particularly as greater numbers take advantage of the changing landscape of postsecondary opportunities.

The Higher Education Opportunities Act of 2008 and the subsequent emergence of Comprehensive Transition Programs (CTPs) across the country opens the door for college opportunities for students who 
were previously overwhelmingly excluded. Though the door to college has opened, there is now also greater understanding of the barriers that exist, at both the student level and the systems level. For students, we must engage them, families, and educators far earlier, and find ways to retain and graduate them. We must also engage and nurture a variety of systems that have previously not been well engaged around higher education and ID. There can be complex problem solving that is needed when various service systems (including Local Education Agencies (LEAs), Institutions of Higher Education (IHEs), state Developmental Disability Authorities (DDAs), and state Vocational Rehabilitation (VR)) must unite in order to develop and sustain meaningful programs. Each system has its unique mission, set of practices, policies and methods.

This research represents a first step in utilizing a nationally recognized instrument that takes a holistic view of outcomes for adults with IDD to assess impact of participation in higher education. While the results are promising, further study using larger samples is warranted.

\section{Conflict of interest}

None to declare.

\section{References}

Bershadsky, J., Butterworth, J., \& Hiersteiner, D. (2014). Working in the community: The status and outcomes of people with intellectual and developmental disabilities in integrated employment - an update. National Core Indicators Data Brief, 1.

Bureau of Labor Statistics. (2015). Persons with a disability: Labor force characteristics- 2014 [News release]. Retrieved from http://www.bls.gov/news.release/pdf/disabl.pdf.

Carnevale, A.P., Smith, N., \& Strohl, J. (2011). Help wanted: Projections of job and education requirements through 2018. Lumina Foundation.

Grigal, M., Hart, D., \& Weir, C. (2012). A survey of postsecondary education programs for students with intellectual disabilities in the United States. Journal of Policy and Practice in Intellectual Disabilities, 9(4), 223-233.

Hong, B.S.S., Ivy, W.F., Gonzalez, H.R., \& Ehrensberger, W. (2007). Preparing students for postsecondary education. Teaching Exceptional Children, 40(1), 32-38.
Lee, S.S. (2009). Overview of the Federal Higher Education Opportunity Act reauthorization. Insight A Think College Brief on Policy, Research \& Practice, 1. Retrieved from http://www.thinkcollege.net/images/stories/HEAC_Overview (1).pdf.

Migliore, A., Butterworh, J., \& Hart, D. (2009). Postsecondary education and employment outcomes for youth with intellectual disabilities. Think College Fast Facts, 1. Retrieved from http://www.thinkcollege.net/images/stories/site_images/pubs/ FF_1.pdf.

National Core Indicators. (n.d). About National Core Indicators. Retrieved from http://www.nationalcoreindicators.org/about/.

National Core Indicators. (2015). Adult consumer survey: 2013/14 final report. Retrieved from http://www.nationalcoreindicators .org/upload/core-indicators/4_23_15_2013-14_ACS_508.pdf.

Ross, J., Marcell, J., Williams, P., \& Carlson, D. (2013). Postsecondary education employment and independent living outcomes of persons with autism and intellectual disability. Journal of Postsecondary Education and Disability, 26(4), 337-351.

Sheppard-Jones, K., Kleinert, H.L., Druckmiller, W., \& Ray, M.K. (2015). Students with intellectual disability in higher education: Adult service provider prospective. Intellectual and Development Disabilities, 53(2), 120-128.

Siperstein, G.N., Parker, R.C., \& Drascher, M. (2013). National snapshot of adults with intellectual disabilities in the labor force. Journal of Vocational Rehabilitation, 39, 157-165.

Smith, F.A., Grigal, M., \& Sulewski, J.S. (2012). Postsecondary education and employment outcomes for transition-age youth with and without disabilities: A secondary analysis of American community survey data. Insight A Think College Brief on Policy, Research \& Practice, 15. Retrieved from: http://www.thinkcollege.net/images/stories/Insight_15.pdf.

Thacker, J., \& Sheppard-Jones, K. (2011). Research brief: Higher education for studentswith intellectual disabilities: A Study of KY OVR counselors. Lexington, KY, USA.

University of Kentucky, Human Development Institute. Retrieved from http://www.hdi.uky.edu/SF/Files/ResearchBrief_Summer 2011.pdf.

United States Department of Labor. (n.d). WIOA overview. Retrieved from http://www.doleta.gov/WIOA/Overview.cfm.

Wagner, M., Newman, L., Cameto, R., \& Levine, P. (2005). Changes Over Time in the Early Postschool Outcomes of Youth with Disabilities. A Report of Findings from the National Longitudinal Transition Study (NLTS) and the National Longitudinal Transition Study-2 (NLTS2). Menlo Park, CA: SRI International. Available at www.nlts2.org/reports/ 2005_06/nlts2_report_2005_06_complete.pdf.

Wagner, M., Newman, L., Cameto, R., Garza, N., \& Levine, P. (2005). After High School: A First Look at the Postschool Experiences of Youth with Disabilities. A Report from the National Longitudinal Transition Study-2 (NLTS2) Menlo Park, CA: SRI International. Available at www.nlts2.org/ reports/2005_04/nlts2_report_2005_04_complete.pdf. 